\title{
Contributions of malaria, helminths, HIV and iron deficiency to anaemia in pregnant women attending ante-natal clinic in SouthWest Nigeria
}

\author{
Olawunmi R Rabiu ${ }^{1,2,3}$, Hannah Dada-Adegbola ${ }^{4}$, Ayokulehin M Kosoko ${ }^{2,5,6}$, Catherine O Falade ${ }^{2,7}$, \\ Olatunbosun G Arinola ${ }^{8}$, Alexander B Odaibo ${ }^{1}$, Olusegun G Ademowo ${ }^{2,7}$
}

1. Department of Zoology, University of Ibadan, Ibadan, Nigeria

2. Institute for Advanced Medical Research and Training, College of Medicine, University of Ibadan, Ibadan, Nigeria.

3. Department of Biological Sciences, Mountain Top University, Km 12, Lagos-Ibadan Expressway, Ogun State, Nigeria.

4. Department of Medical Microbiology and Parasitology, College of Medicine, University of Ibadan, Ibadan, Nigeria.

5. Department of Biochemistry, University of Ibadan, Ibadan, Nigeria.

6. Department of Biochemistry, Federal University of Agriculture, Abeokuta, Ogun State, Nigeria.

7. Department of Pharmacology and Therapeutics, University of Ibadan, Ibadan, Nigeria

8. Immunology Unit, Department of Chemical Pathology, College of Medicine, University of Ibadan, Nigeria.

\section{E-mails:}

Olawunmi R Rabiu: wummier@yahoo.com; Hannah Dada-Adegbola: dadaadegbola@yahoo.com; Ayokulehin M Kosoko: kosoko_am2002@yahoo.com; Catherine O Falade: lillyfunke@yahoo.com; Olatunbosun G Arinola: drarinolaog64@yahoo.com; Alexander B Odaibo: alexodaibo@yahoo.com; Olusegun G Ademowo: ademowo_g@yahoo.com

\begin{abstract}
Background: Iron deficiency is a dominant source of anaemia in many settings. To evaluate the key cause of anaemia in the study area, the prevalence of anaemia due to major public health diseases was compared with anaemia due to iron deficiency. Methods: Pregnant women were recruited from ante-natal $(n=490)$ and HIV clinics $(n=217)$ with their personal data documented using a questionnaire. Microscopy of Giemsa-stained thick smears was used for detection of malaria parasites while helminths in stools were detected using direct smear method. Haematocrit values were determined by capillary method. Serum ferritin levels were determined using enzyme-linked immunosorbent assay. Data was analysed using SPSS version 22.0. Results: The mean age of the recruited women was $28.6 \pm 5.4$ years old. There were $68.1 \%$ cases of anaemia of which $35.5 \%$ was due to infections only predominantly HIV and malaria, $14.9 \%$ from unknown sources while anaemia due to iron deficiency only was $7.1 \%$.

Conclusion: It can safely be inferred that malaria and HIV predispose to anaemia than iron deficiency in the study area. Although pregnant women are dewormed and given IPTp for helminths and malaria treatment respectively, there should be complementary routine malaria screening at ANC visits for those with HCT values $<33 \%$ and those infected with HIV. Keywords: Iron deficiency anaemia; antenatal care; Plasmodium; helminth; pregnant women; HIV.

DOI: https://dx.doi.org/10.4314/ahs.v20i3.6

Cite as: Rabiu OR, Dada-Adegbola H, Kosoko AM, Falade CO, Arinola OG, Odaibo AB, et al. Contributions of malaria, helminths, HIV and iron deficiency to anaemia in pregnant women attending ante-natal clinic in SouthWest Nigeria. Afri Health Sci. 2020;20(3): 10351044. https://dx.doiorg/10.4314/abs.v20i3.6
\end{abstract}

\section{Corresponding author: \\ Olusegun G Ademowo, \\ Institute for Advanced Medical Research and \\ Training, College of Medicine, University of \\ Ibadan, Ibadan, Nigeria. \\ Tel: +2348023342856 . \\ E-mail address: ademowo_g@yahoo.com}

\section{Introduction}

Anaemia is a state of reduced number of red blood cells resulting in lower oxygen-carrying capacity of the cells which invariably affects the body's physiologic functions. According to World Health Organization (WHO), haemoglobin level less than $11 \mathrm{~g} / \mathrm{dl}$ in pregnancy is an indication of anaemia ${ }^{1}$. Anaemia can be caused by nutritional deficiencies, inflammation, parasitic infections, blood loss and haemoglobinopathies

$\begin{array}{lll}\text { African } & \text { C } 2020 \text { Rabiu OR et al. Licensee African Health Sciences. This is an Open Access article distributed under the terms of the Creative commons Attribution } \\ \text { Health Sciences } & \text { License (https://creativecommons.org/licenses/BY/4.0), which permits unrestricted use, distribution, and reproduction in any medium, provided the original }\end{array}$ License (https://creativecommons.org/licenses/BY/4.0), which permits unrestricted use, distribution, and reproduction in any medium, provided the original
work is properly cited. 
with iron deficiency being reported as the major cause of anaemia ${ }^{2,3}$. Globally, an estimated $41.8 \%$ pregnant women are reported to be anaemic and in about half of these women, anaemia is presumed to be due to iron deficiency ${ }^{4}$. High prevalence of anaemia in pregnancy led to the recommendation of the WHO guideline for daily iron and folic acid supplementation in pregnancy to reduce the risk of low birth weight babies, maternal anaemia and iron deficiency ${ }^{4}$. However, overview of studies conducted in Nigeria have reported persistent high prevalence of anaemia among pregnant women ${ }^{5-8}$. This necessitated the need to evaluate other underlying causes of anaemia.

Malaria, helminths and human immunodeficiency virus (HIV) are common diseases in poor countries and have been associated with anaemia in pregnancy ${ }^{5,9-17}$. The burden of anaemia associated with these infections should be minimal if there were strict adherences to the WHO guidelines for use of Intermittent Preventive Treatment in pregnancy (IPTp) for control of malaria ${ }^{18}$ and deworming regimen to reduce burden of helminthiasis in pregnancy ${ }^{19}$. However, poor compliance with IPTp usage has been reported ${ }^{15,20,21}$ thus proposing a multidimensional approach to resolving the burden of anaemia in pregnancy. The focus of this study was therefore to conduct a comparative analysis of the relative contribution of these infections and iron deficiency to anaemia among pregnant women in SouthWest Nigeria.

\section{Methods}

\section{Study site, design and study population}

This study was carried out in Adeoyo Maternity Hospital, a secondary healthcare facility and Agbongbon Primary Healthcare Centre in Ibadan, Southwest Nigeria. They are government owned and serves the local inhabitants who are predominantly petty traders and home makers. The average attendances at each ante-natal clinic visit of these hospitals are about 120 and 25 pregnant women respectively.

This is a cross-sectional study with inclusion and exclusion criteria as follows:

Inclusion criteria: Pregnant women between 18-45 years old were recruited at their first antenatal visit. Confirmed HIV infected pregnant women were recruited from the HIV clinic situated within the secondary healthcare facility. Informed consent was obtained from all the women at recruitment. Only patients from whom both blood and stool samples were collected were included in the study.

Exclusion criteria: Pregnant women with observable complications were excluded. At the regular antenatal clinic, pregnant women that tested positive for HIV during the hospital routine tests at booking were excluded. They were referred to HIV clinic for confirmatory testing.

Overall, 707 pregnant women were recruited. They comprised of 490 HIV negative pregnant women recruited from the ante-natal clinics (ANCs) and 217 HIV positive from the HIV clinic. Well-structured close-ended questionnaires were administered by trained data collectors in the native language of the subjects (Yoruba) as majority of them were semi-literate. These provided information on socio-demographic details, educational history, sanitary practices and living conditions.

Ethical approvals for this work were obtained from Oyo State Ministry of Health and the University of Ibadan/ University College Hospital Ethical Review Committees. Individual informed consent was obtained from each enrollee before study related procedures were carried out.

\section{Sample size}

The sample size was calculated using the formula below at a $25 \%$ expected prevalence rate $(\mathrm{P})$ and a precision (d) of 0.05 (22).

$$
\begin{aligned}
& \frac{\mathrm{n}=\mathrm{Z}^{2} \mathrm{P}(1-\mathrm{P})}{\mathrm{d}^{2}} \\
& \mathrm{n}=\frac{(1.96)^{2} \times 0.25(1-0.25)}{(0.05)^{2}}=286
\end{aligned}
$$

A minimum of 314 pregnant women were proposed to be recruited having added $10 \%$ of the calculated value to suffice for unexpected outcomes.

\section{Anaemia assessment}

\section{Haematocrit (HCT)}

Venous blood was withdrawn into heparinized capillary tube and sealed at one end with plasticine. The tubes were spun at $3000 \mathrm{rpm}$ for 10 mins in a microhaematocrit centrifuge (Hawksley Ltd, Lancing, UK) and read with Hawksley haematocrit reader. In pregnancy HCT levels $<33 \%$ was taken as an indication of anaemia ${ }^{1}$.

\section{Serum ferritin (SF)}

Five millilitres of blood was collected by venipuncture into plain tubes and spun at $3000 \mathrm{~g}$ for $5 \mathrm{mins}$ in a centrifuge. Serum samples were stored at $-20^{\circ} \mathrm{C}$ until when the ferritin levels were determined using enzyme linked immunosorbent assay (ELISA) kits obtained from Assaypro, USA and the assay was performed according to manufacturer's instructions. Standard curves were generated and data interpreted using Curve Expert 1.4 software. 


\section{Parasitological assessment}

Thick blood smears were prepared on microscope slides for each participant and allowed to air dry away from direct sunlight. Dried smears were stained with fresh Giemsa stain at $\mathrm{pH} 7.2$ using standard procedures and were subsequently screened under light microscope at x1000 magnification for presence and quantification of asexual stage of malaria parasite. Definitive parasite density was calculated as number of parasites counted against about 200 white blood cells using an assumed white blood cell count of $8000 / \mathrm{mm}^{3}{ }^{23}$. Intestinal helminths were identified by microscopic examination of saline preparation of stool on a glass slide covered with cover slip. Kato-Katz technique was used for quantification of helminth ova ${ }^{24}$.

\section{Data analysis}

Statistical package, SPSS version 22.0 (IBM ${ }^{\circledR}$ SPSS ${ }^{\circledR}$, Chicago, IL, USA) was used for the data analysis. Prevalence values were determined using descriptive statistics.
Pearson Chi-Square was used to test for associations while Student t-test was used to determine significant differences in mean values between two groups. Significant level was set at $\mathrm{p}<0.05$. Iron deficiency anaemia was defined as HCT $<33 \%$ and serum ferritin values $<12 \mathrm{ng} / \mathrm{ml}$ or $<30 \mathrm{ng} / \mathrm{ml}$ based on infection status ${ }^{25}$. Using WHO reference values, SF values $<12 \mathrm{ng} / \mathrm{ml}$ was used as cut-off among those without infection and the cut-off was raised to $30 \mathrm{ng} / \mathrm{ml}$ for those infected ${ }^{26}$.

\section{Results}

The mean age of the 707 recruited pregnant women was $28.6 \pm 5.4$ yrs old. They were mostly multigravids $(75.1 \%)$ and secondary school leavers $(56.9 \%)$. The major occupation of the recruited women was trading mostly in food and food items (54.4\%). Drawing water from deep wells with the use of bucket and rope was the major source of portable water and $5.4 \%$ of the women had no toilet in the house. Table 1 shows details of the socio-demographic status of the women.

\begin{tabular}{|c|c|c|c|}
\hline Characteristics & $\mathrm{N}$ & Status & $\mathrm{n}(\%)$ \\
\hline \multirow[t]{5}{*}{ Age } & 700 & $<20$ years & $22(3.1)$ \\
\hline & & 20-34 years & 564 \\
\hline & & & $(80.6)$ \\
\hline & & $\geq 35$ years & 114 \\
\hline & & & $(16.3)$ \\
\hline \multirow[t]{4}{*}{ Gravidity } & 695 & Primigravidae & 173 \\
\hline & & & $(24.9)$ \\
\hline & & Multigravidae & 522 \\
\hline & & & $(75.1)$ \\
\hline \multirow[t]{7}{*}{ Level of education } & 703 & None & $5(0.7)$ \\
\hline & & Primary/quranic & 138 \\
\hline & & & $(19.6)$ \\
\hline & & Secondary & 400 \\
\hline & & & $(56.9)$ \\
\hline & & Post-secondary & 160 \\
\hline & & & $(22.8)$ \\
\hline \multirow[t]{9}{*}{ Occupation } & 702 & Student/Unemployed & $52(7.4)$ \\
\hline & & Petty trader & 382 \\
\hline & & & $(54.4)$ \\
\hline & & Primary school teacher/Junior & 188 \\
\hline & & civil servant/Artisan & $(26.8)$ \\
\hline & & High school teacher/Middle level & $62(8.8)$ \\
\hline & & civil servant/Middle businessman & \\
\hline & & business & $18(2.6)$ \\
\hline & & person/Professional & \\
\hline \multirow{7}{*}{$\begin{array}{l}\text { Source } \\
\text { water }\end{array}$} & 706 & None & $1(0.1)$ \\
\hline & & Well with pump & $40(5.7)$ \\
\hline & & Well with bucket and rope & 452 \\
\hline & & & $(64.0)$ \\
\hline & & Pipe-borne water & $72(10.2)$ \\
\hline & & Borehole & 141 \\
\hline & & & $(20.0)$ \\
\hline \multirow[t]{4}{*}{ Toilet facility } & 705 & None & $38(5.4)$ \\
\hline & & Pit latrine & 315 \\
\hline & & & $(44.7)$ \\
\hline & & Water system & 352 \\
\hline
\end{tabular}


Sixty-seven (9.4\%) had co-infections (Plasmodium and helminths $-1.1 \%$, Plasmodium and HIV $-7.4 \%$, HIV and helminths $-0.8 \%$, Plasmodium, HIV and helminths - $0.1 \%$ ) while $258(36.4 \%)$ had single infections (Plasmodium - 7.5\%, Helminth - 6.6\%, HIV - 22.3\%). A higher proportion $(54 \%)$ of the recruited women were uninfected. The helminths found were Ascaris lumbricoides, Trichuris trichiura and hookworms. The mean haematocrit value (HCT) of the recruited women was
$31.7 \pm 5.4 \%$ and $387(57.6 \%)$ of the pregnant women were anaemic (mild anaemia $-24.0 \%$, moderate anaemia $-32.0 \%$, severe anaemia $-1.6 \%$ ). Relative to the mean HCT of the uninfected group $(32.9 \pm 5.6 \%)$, HCT was lower in all the infected groups and these were significantly lower among those with co-infection of Plasmodium and HIV $(29.7 \pm 4.8 \%)$ and those with single infections of HIV $(29.3 \pm 5.0 \%)$ and Plasmodium $(31.0 \pm 4.0 \%)$ as shown in Table 2 .

Table 2: Mean HCT values and anaemia classification in relation to infection status.

\begin{tabular}{|c|c|c|c|c|c|c|}
\hline Groups & $\mathrm{n}$ & Mean \pm SD & $\begin{array}{l}\% \\
\text { anaemia }\end{array}$ & Mild & Moderate & Severe \\
\hline $\mathrm{PF}$ & 53 & $31.0 \pm 4.0^{\mathrm{a}}$ & 60.4 & $16(30.2 \%)$ & $16(30.2 \%)$ & -- \\
\hline $\mathrm{H}$ & 44 & $32.2 \pm 5.0$ & 54.5 & $11(25.0 \%)$ & $13(29.5 \%)$ & -- \\
\hline HIV & 143 & $29.3 \pm 5.0^{\mathrm{b}}$ & 76.2 & $39(27.3 \%)$ & $64(44.8 \%)$ & $\begin{array}{l}6 \\
(4.2 \%)\end{array}$ \\
\hline $\mathrm{PF}+\mathrm{H}$ & 8 & $29.9 \pm 4.7$ & 75 & $3(37.5 \%)$ & $3(37.5 \%)$ & -- \\
\hline $\mathrm{H}+\mathrm{HIV}$ & 5 & $30.6 \pm 4.0$ & 80 & $2(40.0 \%)$ & $2(40.0 \%)$ & -- \\
\hline $\mathrm{PF}+\mathrm{HIV}$ & 48 & $29.7 \pm 4.8^{c}$ & 72.9 & $15(31.3 \%)$ & $18(37.5 \%)$ & $\begin{array}{l}2 \\
(4.2 \%)\end{array}$ \\
\hline $\mathrm{PF}+\mathrm{H}+\mathrm{HIV}$ & 1 & 27.0 & 100 & -- & $1(100 \%)$ & -- \\
\hline Uninfected & 370 & $32.9 \pm 5.6^{\mathrm{a}, \mathrm{b}, \mathrm{c}}$ & 47.6 & $75(20.3 \%)$ & $98(26.5 \%)$ & $\begin{array}{l}3 \\
(0.8 \%) \\
\end{array}$ \\
\hline
\end{tabular}

Key: $\mathrm{PF}-$ P. falciparum, $\mathrm{H}$ - Helminth, $\mathrm{SD}$ - standard deviation

Similar superscripts show significant difference at $\mathrm{p}<0.05$

A significantly higher proportion of those with P. falciparum infection (67.3\%) and HIV (75.6\%) were anaemic while the proportion of those with helminth infection and who had anaemia $(60.3 \%)$ was not statistically significant from those without anaemia (Table 3 ). 
Table 3: Association between anaemia and infections

\begin{tabular}{|c|c|c|c|c|c|}
\hline Anaemia & $\begin{array}{l}\mathrm{PF} \\
\text { positive }\end{array}$ & $\begin{array}{l}\mathrm{PF} \\
\text { negative }\end{array}$ & Total & $\chi^{2}$ & $P$-value \\
\hline Present & $\begin{array}{l}74 \\
(67.3 \%)\end{array}$ & $\begin{array}{l}313 \\
(55.7 \%)\end{array}$ & $\begin{array}{l}387 \\
(57.6 \%)\end{array}$ & & \\
\hline Absent & $\begin{array}{l}36 \\
(32.7 \%)\end{array}$ & $\begin{array}{l}249 \\
(44.3 \%)\end{array}$ & $\begin{array}{l}285 \\
(42.4 \%)\end{array}$ & & \\
\hline Total & $\begin{array}{l}110 \\
(100 \%)\end{array}$ & $\begin{array}{l}562 \\
(100 \%)\end{array}$ & $\begin{array}{l}672 \\
(100 \%)\end{array}$ & 5.050 & $0.025^{*}$ \\
\hline & $\mathrm{H}$ positive & $\mathrm{H}$ negative & Total & & \\
\hline Present & $\begin{array}{l}35 \\
(60.3 \%)\end{array}$ & $\begin{array}{l}352 \\
(57.3 \%)\end{array}$ & $\begin{array}{l}387 \\
(57.6 \%)\end{array}$ & & \\
\hline Absent & $\begin{array}{l}23 \\
(39.7 \%)\end{array}$ & $\begin{array}{l}262 \\
(42.7 \%)\end{array}$ & $\begin{array}{l}285 \\
(42.4 \%)\end{array}$ & & \\
\hline Total & $\begin{array}{l}58 \\
(100 \%)\end{array}$ & $\begin{array}{l}614 \\
(100 \%)\end{array}$ & $\begin{array}{l}672 \\
(100 \%)\end{array}$ & 0.197 & 0.657 \\
\hline & $\begin{array}{l}\text { HIV } \\
\text { positive }\end{array}$ & $\begin{array}{l}\text { HIV } \\
\text { negative }\end{array}$ & Total & & \\
\hline Present & $\begin{array}{c}149 \\
(75.6 \%)\end{array}$ & $\begin{array}{l}238 \\
(50.1 \%)\end{array}$ & $\begin{array}{l}387 \\
(57.6 \%)\end{array}$ & & \\
\hline Absent & $\begin{array}{l}48 \\
(24.4 \%)\end{array}$ & $\begin{array}{l}237 \\
(49.9 \%)\end{array}$ & $\begin{array}{l}285 \\
(42.4 \%)\end{array}$ & & \\
\hline Total & $\begin{array}{l}197 \\
(100 \%)\end{array}$ & $\begin{array}{l}475 \\
(100 \%)\end{array}$ & $\begin{array}{l}672 \\
(100 \%)\end{array}$ & 37.158 & $<0.0001^{*}$ \\
\hline
\end{tabular}

Key: $\mathrm{PF}-P$. falciparum, $\mathrm{H}-$ Helminth $\quad$ *significant at $\mathrm{p}<0.05$

From the larger population of 707 recruited pregnant women, serum samples of 141 women were selected across the infection groups for determination of serum ferritin levels and the results were grouped as iron deficient only, or iron deficiency anaemia. As shown in Table 4 , there was $68.1 \%(96 / 141)$ prevalence of anaemia and $26.0 \%(25 / 96)$ of the anaemia cases were due to iron deficiency. A small proportion of those who were infected with Plasmodium, helminths or HIV were also iron deficient. Hence, the test of associations between these infections and iron deficiency were not statistically significant. Similarly, the test of association between anaemia and iron deficiency was not significant. 
Table 4: Association between iron deficiency, anaemia and infections.

\begin{tabular}{|c|c|c|c|c|c|}
\hline & PF positive & PF negative & Total & $\chi^{2}$ & $P$-value \\
\hline $\begin{array}{l}\text { Iron } \\
\text { deficient }\end{array}$ & $10(19.2 \%)$ & $21(23.6 \%)$ & $31(21.4 \%)$ & & \\
\hline Normal & $42(80.8 \%)$ & $68(76.4 \%)$ & $110(78.6 \%)$ & & \\
\hline Total & $52(100 \%)$ & $89(100 \%)$ & $141(100 \%)$ & 0.365 & 0.546 \\
\hline & $\mathrm{H}$ positive & $\mathrm{H}$ negative & Total & & \\
\hline $\begin{array}{l}\text { Iron } \\
\text { deficient }\end{array}$ & $4(17.4 \%)$ & $27(22.9 \%)$ & $31(22 \%)$ & & \\
\hline Normal & $19(82.6 \%)$ & $91(77.1 \%)$ & $110(78 \%)$ & & \\
\hline Total & $23(100 \%)$ & $118(100 \%)$ & $141(100 \%)$ & 0.338 & 0.561 \\
\hline & $\begin{array}{l}\text { HIV } \\
\text { positive }\end{array}$ & $\begin{array}{l}\text { HIV } \\
\text { negative }\end{array}$ & Total & & \\
\hline $\begin{array}{l}\text { Iron } \\
\text { deficient }\end{array}$ & $13(24.5 \%)$ & $18(20.5 \%)$ & $31(22 \%)$ & & \\
\hline Normal & $40(75.5 \%)$ & $70(79.5 \%)$ & $110(78 \%)$ & & \\
\hline Total & $\begin{array}{l}53(100 \%) \\
\text { Anaemia } \\
\text { present }\end{array}$ & $\begin{array}{l}88(100 \%) \\
\text { Anaemia } \\
\text { absent }\end{array}$ & $\begin{array}{l}141(100 \%) \\
\text { Total }\end{array}$ & 0.320 & 0.572 \\
\hline $\begin{array}{l}\text { Iron } \\
\text { deficient }\end{array}$ & $25(26.0 \%)$ & $6(13.3 \%)$ & $31(22.0 \%)$ & & \\
\hline Normal & $71(74.0 \%)$ & $39(86.7 \%)$ & $110(78.0 \%)$ & & \\
\hline Total & $96(100 \%)$ & $45(100 \%)$ & $141(100 \%)$ & 2.885 & 0.089 \\
\hline
\end{tabular}

Key: $\mathrm{PF}-P$. falciparum, $\mathrm{H}-$ Helminth

Table 5 shows the distribution of iron deficiency and anaemia according to the infection status. The prevalence of iron deficiency anaemia among the pregnant women irrespective of the infection status was $17.7 \%$ $(25 / 141)$ while the prevalence of anaemia without iron deficiency was $50.4 \%$ (71/141). The prevalence of iron deficiency anaemia without the compounding ef- fect of infection was 7.1\% (10/141). The prevalence of anaemia associated with infection only was $35.5 \%$ (50/141). The prevalence of anaemia due to unknown sources (absence of infection and no iron deficiency) was $14.9 \%$ (21/141). Iron deficiency anaemia was more prevalent among those infected with HIV only and the uninfected group. 
Table 5: Prevalence of anaemia and iron deficiency in relation to infection status

\begin{tabular}{|c|c|c|c|c|c|}
\hline & $\mathrm{n}$ & $\begin{array}{l}\text { Normal HCT/ } \\
\text { ferritin levels }\end{array}$ & $\begin{array}{c}\text { Anaemia } \\
\text { only }\end{array}$ & $\begin{array}{c}\text { Iron } \\
\text { deficiency } \\
\text { only }\end{array}$ & $\begin{array}{c}\text { Iron deficiency } \\
\text { anaemia }\end{array}$ \\
\hline Plasmodium only & 23 & $8(34.8 \%)$ & $\begin{array}{l}12 \\
(52.2 \%)\end{array}$ & $2(8.7 \%)$ & $1(4.3 \%)$ \\
\hline Helminth only & 18 & $9(50 \%)$ & $6(33.3 \%)$ & $2(11.1 \%)$ & $1(5.6 \%)$ \\
\hline HIV only & 29 & $4(13.8 \%)$ & $\begin{array}{l}18 \\
(62.1 \%)\end{array}$ & - & $7(24.1 \%)$ \\
\hline Plasmodium/Helminth & 5 & $1(20 \%)$ & $3(60 \%)$ & - & $1(20 \%)$ \\
\hline Plasmodium/HIV & 24 & $7(29.2 \%)$ & $\begin{array}{l}11 \\
(45.8 \%)\end{array}$ & $1(4.2 \%)$ & $5(20.8 \%)$ \\
\hline Uninfected & 42 & $10(23.8 \%)$ & $21(50 \%)$ & $1(2.4 \%)$ & $10(23.8 \%)$ \\
\hline Total & 141 & $39(27.7 \%)$ & $\begin{array}{l}71 \\
(50.4 \%)\end{array}$ & $6(4.3 \%)$ & $25(17.7 \%)$ \\
\hline
\end{tabular}

\section{Discussion}

Anaemia is a common complication of pregnancy in tropical African countries where poverty related infectious diseases are endemic. We therefore evaluated the prevalence of anaemia due to infection and iron deficiency to establish the need to complement the current interventions of iron supplementation and intermittent preventive treatment of malaria in pregnancy.

The prevalence of anaemia among the pregnant women was $68.1 \%$. Similar findings of more than half of the pregnant women being anaemic have been reported within and outside Nigeria ${ }^{5-7,9,11,27}$. However, some other studies reported $<30 \%$ prevalence of anaemia among pregnant women ${ }^{8,28-30}$. Data showed that Plasmodium, helminth and HIV infections caused reduction in HCT values. The differences were found to be significant in Plasmodium and HIV infections relative to the uninfected group. Some studies have likewise reported reduction in HCT values among those with Plasmodium infection ${ }^{5,31}$. It is established that destruction of red blood cells, a key feature of malaria pathogenesis will predispose to anaemia ${ }^{32}$. Likewise, reduction in HCT values in HIV infections has been reported by some authors ${ }^{14,29}$. Moreover, there was a strong association between anaemia and Plasmodium and HIV infections. This supports earlier reports of a strong association between severity of parasitaemia and degree of anaemia ${ }^{5,11,14,33}$. Anaemia in HIV infection has been linked to progression of the disease, poor quality of life and

higher mortality ${ }^{34}$. Furthermore, there was no significant association in either of the three infections studied and iron deficiency. Although there is a deficit of data on SF levels among helminth infected pregnant women, a study among school children showed no significant association between iron deficiency and ascariasis as obtained in this study ${ }^{35}$. Another study among school children also found no significant association between iron deficiency and ascariasis. According to their findings, severe trichuriasis was the major contributor to iron deficiency ${ }^{36}$. Hookworms and Trichuris seem to be the major causes of iron deficiency ${ }^{36,37}$. Among the three predominant worms; hookworms, Ascaris and Trichuris, hookworms are more likely to be strongly associated to low serum ferritin levels because of their migratory behaviour leaving many bleeding spots leading to intestinal blood losses ${ }^{38}$. Likewise, there was no significant association between iron deficiency and anaemia in this present study. However, a study of pregnant women in Uganda showed a significant association between them ${ }^{33}$. The difference in findings may be due to variation in cut-off values for ferritin in these studies. A cut-off of $<12 \mu \mathrm{g} / 1$ was used in this study for those without infection and $<30 \mu \mathrm{g} / 1$ for those with infection while they used $<30 \mu \mathrm{g} / \mathrm{l}$ as a general cut-off value.

This study further substantiated the evidence of high prevalence of anaemia among pregnant women and infection has been identified as the major cause of anaemia in this setting. With the removal of confounders, 
there was a low prevalence $(7.1 \%)$ of iron deficiency anaemia (IDA) while the prevalence of infection associated anaemia was $35.5 \%$ with HIV infection being the highest contributor to anaemia. Contrary to this finding, iron deficiency is reportedly the dominant cause of anaemia in some settings ${ }^{27,36}$. This low prevalence of IDA showed that nutritional deficiency may not be a major public health issue among the pregnant women in this present study. Hence, strategic policies to reduce the burden of these infections in pregnancy is highly required as quite a number of malaria cases are undetected when there are no clinical symptoms. This was observed among these pregnant women at booking. Presently, there is no guideline for routine screening for malaria and helminths in ante natal clinics in healthcare facilities in Nigeria. Hence, there is likelihood of these women remaining untreated as the adopted intermittent presumptive treatment in pregnancy (IPTp) has recorded cases of poor compliance ${ }^{15,20,21}$. Furthermore, the effect of iron supplementation on reducing the burden of anaemia in pregnancy may be masked without concurrent treatment of underlying infection.

\section{Conclusion}

The high burden of anaemia in the study population is largely due to the presence of infection and not deficiency of iron. Further research on the impact of treatment on prevalence of anaemia among pregnant women infected with malaria parasitaemia or helminthiasis may lay further credence to the need for routine screening during ante-natal visits.

\section{Conflict of interest}

The authors declare no conflict of interest.

\section{Funding statement}

This work is part of a larger project funded by European Community's Seventh Framework Programme (HEALTH-F3-2009-241642) and also supported by the Institute of Infectious Diseases of Poverty (IIDP) Scholarship Award ID Number 2013/08 from 2013 to 2016 awarded to ORR. None of the funding sources were involved in study design, collection, analysis and interpretation of the data, in the writing of the paper or in the decision to submit the paper for publication.

\section{Acknowledgements}

The participants, field and laboratory staff are duly acknowledged for their participation in the study.

\section{References}

1. World Health Organization. Haemoglobin con- centrations for the diagnosis of anaemia and assessment of severity [Internet]. 2011. 1-6 p. Available from: http://scholar.google.com/scholar?hl=en\&bt$n G=$ Search\&q=intitle:Haemoglobin + concentrations + for + the + diagnosis + of + anaemia + and + assessment + of + severity \#1

2. World Health Organisation. Worldwide prevalence of anaemia. 2005;

3. Dreyfuss ML, Stoltzfus RJ, Shrestha JB, Pradhan EK, Leclerq SC, Khatry SK, et al. Community and International Nutrition Hookworms, Malaria and Vitamin A Deficiency Contribute to Anemia and Iron Deficiency among Pregnant Women in the Plains of Nepal 1. 2000;(February):2527-36.

4. World Health Organisation. Guideline: Daily iron and folic acid supplementation in pregnant women. WHO Guidel. 2012;

5. Agan TU, Ekabua JE, Udoh AE, Ekanem EI, Efiok EE Mgbekem MA. Prevalence of anemia in women with asymptomatic malaria parasitemia at first antenatal care visit at the University of Calabar. Int J Womens Health. 2010;2010(2):229-33.

6. Olatunbosun OA, Abasiattai AM, Bassey EA, James RS, Ibanga G, Morgan A. Prevalence of anaemia among pregnant women at booking in the University of Uyo Teaching Hospital, Uyo, Nigeria. Biomed Res Int [Internet]. 2014 Jan;2014. Available from: http:// www.pubmedcentral.nih.gov/articlerender.fcgi?artid $=4055238 \&$ tool $=$ pmcentrez\&rendertype $=$ abstract

7. Idowu OA, Mafiana CF, Dapo S. Anaemia in pregnancy : a survey of pregnant women in Abeokuta. Afr Health Sci. 2005;5(4):295-9.

8. Gwarzo MY, Ugwa EA. The pattern of anaemia in northern Nigerian pregnant women. J Med Med Sci. 2013;4(8):319-23.

9. McClure EM, Meshnick SR, Mungai P, Malhotra I, King CL, Goldenberg RL, et al. The association of parasitic infections in pregnancy and maternal and fetal anemia: a cohort study in coastal Kenya. PLoS Negl Trop Dis [Internet]. 2014 Feb [cited 2015 Jul 2];8(2):e2724. Available from: http://www.pubmedcentral.nih. gov $/$ articlerender.fcgi? artid $=3937317 \&$ tool $=$ pmcentrez\&rendertype $=$ abstract

10. Oladeinde BH, Omoregie R, Odia I, Oladeinde OB. Prevalence of Malaria and Anemia among Pregnant Women Attending a Traditional Birth Home in Benin City, Nigeria. Oman MedJ [Internet]. 2012 May;27(3):232-

6. Available from: http://www.pubmedcentral.nih. gov $/$ articlerender.fcgi? artid $=3394357 \&$ tool=pmcen trez\&rendertype $=$ abstract

11. Ouma P, van Eijk AM, Hamel MJ, Parise M, Ayisi JG, Otieno K, et al. Malaria and anaemia among preg- 
nant women at first antenatal clinic visit in Kisumu, western Kenya. Trop Med Int Health [Internet]. 2007 Dec [cited 2015 Jul 2];12(12):1515-23. Available from: http://www.ncbi.nlm.nih.gov/pubmed/18076560

12. Wekesa AW, Mulambalah CS, Muleke CI, Odhiambo R. Intestinal helminth infections in pregnant women attending antenatal clinic at kitale district hospital, Kenya. J Parasitol Res [Internet]. 2014 Jan;2014:823923. Available from: http://www.pubmedcentral.nih.gov/articlerender.fcgi? artid $=4058276 \&$ tool $=$ pmcentrez\&rendertype $=$ abstract

13. Ndibazza J, Muhangi L, Akishule D, Kiggundu M, Ameke C, Oweka J, et al. Effects of Deworming during Pregnancy on Maternal and Perinatal Outcomes in Entebbe, Uganda: A Randomized Controlled Trial. Clin Infect Dis [Internet]. 2010 Feb 15 [cited 2015 Jul 2];50(4):531-40. Available from: http://cid.oxfordjournals.org/lookup/doi/10.1086/649924

14. Muhangi L, Woodburn P, Omara M, Omoding N, Kizito D, Mpairwe H, et al. Associations between mild-to-moderate anaemia in pregnancy and helminth, malaria and HIV infection in Entebbe, Uganda. [Internet]. Vol. 101, Transactions of the Royal Society of Tropical Medicine and Hygiene. 2007. p. 899-907. Available from: http://www.pubmedcentral.nih.gov/articlerender.fcgi?artid =1950430\&tool=pmcentrez\&rendertype $=$ abstract

15. Oladokun A, Oladokun RE, Adesina OA. Knowledge and utilization of malaria control measures by pregnant and newly delivered mothers in Ibadan, Nigeria. Afr Health Sci. 2012;11(4):573-7.

16. Nandlal V, Moodley D, Grobler A, Bagratee J, Maharaj NR, Richardson P. Anaemia in pregnancy is associated with advanced HIV disease. PLoS One [Internet]. 2014 Jan [cited 2015 Jul 2];9(9):e106103. Available from: http://www.pubmedcentral.nih.gov/articlerender.fcgi? artid $=4164466 \&$ tool=pmcentrez\&rendertype $=$ abstract

17. Manyanga VP, Minzi O, Ngasala B. Prevalence of malaria and anaemia among HIV infected pregnant women receiving co-trimoxazole prophylaxis in Tanzania: a cross sectional study in Kinondoni Municipality. BMC Pharmacol Toxicol [Internet]. 2014 Jan [cited 2015 Jul 2];15(1):24. Available from: http:/ / www.pubmedcentral.nih.gov / articlerender.fcgi? artid $=4014408 \&$ tool $=p-$ mcentrez\&rendertype $=$ abstract

18. World Health Organisation. Updated WHO Policy Recommendation ( October 2012 ) Intermittent Preventive Treatment of malaria in pregnancy using Sulfadoxine- Pyrimethamine ( IPTP-SP ). 2012;(October):3-4.
19. World Health Organisation. Preventive chemotherapy in human helminthiasis Preventive chemotherapy in human helminthiasis. 2006;

20. Akinleye SO, Falade CO, Ajayi IO. Knowledge and utilization of intermittent preventive treatment for malaria among pregnant women attending antenatal clinics in primary health care centers in rural southwest, Nigeria: a cross-sectional study. BMC Pregnancy Childbirth [Internet]. 2009 Jan [cited 2015 Jul 1];9:28. Available from: http://www.pubmedcentral.nih.gov/articlerender.fcgi? artid $=2719593 \&$ tool $=$ pmcentrez\&rendertype $=$ abstract

21. Arulogun OS, Okereke CC. Knowledge and practices of intermittent preventive treatment of malaria in pregnancy among health workers in a southwest local government area of Nigeria. J Med Med Sci. 2012;3(July):415-22.

22. Naing L, Winn T, Rusli BN. Practical Issues in Calculating the Sample Size for Prevalence Studies. Arch Orofac Sci 2006;(1):9-14.

23. World Health Organization. Basic Malaria Microscopy Part I. Learner's Guide. Second. 2010. 1-80 p.

24. World Health Organisation. Training manual on diagnosis of based on the WHO Bench Aids for the diagnosis of intestinal parasites Tutor's Guide Schistosomiasis and Intestinal Parasites Unit Division of Control of Tropical Diseases World Health Organization. 2004; 25. World Health Organisation. Assessing the Iron Status of populations: including literature reviews: report of a Joint World Health Organization/Centers for Disease Control and Prevention Technical Consultation on the Assessment of Iron Status at the Population Level, Geneva, Switzer. 2007.

26. World Health Organisation. Serum ferritin concentrations for the assessment of iron status and iron deficiency in populations. 2011;1-5.

27. Baidoo SE, Tay SCK, Abruquah HH. Intestinal helminth infection and anaemia during pregnancy: A community based study in Ghana. African J Microbiol Res [Internet]. 2010;4(16):1713-8. Available from: http://www.scopus.com/inward/record. url? eid=2-s 2.0-77957978254\&partnerID $=40 \& \mathrm{~m}-$ d5=4df03b8c57383889e64bfdcde7b5d 992

28. Falade CO, Dada-Adegbola HO, Aimakhu CO, Ademowo OG, Salako LA. Prevalence of malaria at booking among antenatal clients in a secondary health care facility in Ibadan, Nigeria. Afr J Reprod Health [Internet]. 2008 [cited 2019 May 11];12(2):141-52. Available from: http://www.bioline.org.br/pdf?rh08030

29. Melku M, Addis Z, Alem M, Enawgaw B. Preva- 
lence and Predictors of Maternal Anemia during Pregnancy in Gondar, Northwest Ethiopia: An Institutional Based Cross-Sectional Study. Anemia [Internet]. 2014 Jan;2014. Available from: http://www.pubmedcentral. nih.gov / articlerender.fcgi? artid $=3942101 \&$ tool $=$ pmcentrez\&rendertype $=$ abstract

30. Okunade K., Adegbesan-Omilabu M. Anaemia among pregnant women at the booking clinic of a teaching hospital in south-western Nigeria. Int J Med Biomed Res [Internet]. 2014 Jul 26 [cited 2019 May 14];114-20. Available from: http://www.ijmbr.com/ reviewed/3.2.7.pdf

31. Ifeanyi OE, Chibunna OM, Braxton NAQ, Uche EC. Impact of Plasmodium falciparum malaria and hookworm infection on anaemia among pregnant women of ikwuano local government area, Abia state, Nigeria. Int J Curr Microbiol Appl Sci. 2014;3(1):104-11.

32. Pradhan P. Malarial anaemia and nitric oxide induced megaloblastic anaemia: a review on the causes of malarial anaemia [Internet]. Vol. 46, J Vector Borne Dis. 2009 [cited 2019 May 14]. Available from: http://www. mrcindia.org/journal/issues/462100.pdf

33. Ndyomugyenyi R, Kabatereine N, Olsen A, Magnussen P. Malaria and hookworm infections in relation to haemoglobin and serum ferritin levels in pregnancy in Masindi district, western Uganda. Trans R Soc Trop Med Hyg. 2008;102:130-6 PubMed .

34. Volberding PA, Levine AM, Dieterich D, Mildvan D, Mitsuyasu R, Saag M. Anemia in HIV Infection: Clinical Impact and Evidence-Based Management Strategies. Clin Infect Dis [Internet]. 2004 May 15 [cited 2019 May 14];38(10):1454-63. Available from: https://academic. oup.com/cid/article-lookup/doi/10.1086/383031

35. Adebara OV, Ernest SK, Ojuawo IA. Association between intestinal helminthiasis and serum ferritin levels among school children. Open J Pediatr. 2011;1:12-6 PubMed .

36. Aini UN, Al-mekhlafi MSH, Azlin M, Shaik A, Sa'iah A, Fatmah M, et al. Serum iron status in Orang Asli children living in endemic areas of soil-transmitted helminths. Asia Pac J Clin Nutr. 2007;16(4):724-30.

37. Nurdiati DS, Sumarni S, Hakimi M, Winkvist A. Impact of intestinal helminth infection on anemia and iron status during pregnancy: Southeast Asian J Trop Med Public Health. 2001;32(1):14-22.

38. Foy H, Kondi A. Hookworms in the aetiology of tropical iron deficiency anaemia. Trans $R$ Soc Trop Med Hyg [Internet]. 1960 Sep 1 [cited 2019 May 14];54(5):419-33. Available from: https://academic. oup.com/trstmh/article-lookup/doi/10.1016/00359203(60)90087-0 